Volume. 5 Number. 2

Period: July - December 2021; page 48-54

p-ISSN : 2580-1112; e-ISSN : 2655-6669

Copyrighr @2020

The author owns the copyright of this article

journal homepage: https://ejournal.akperfatmawati.ac.id

DOI : 10.46749/jiko.v5i2.72
Jurnal Ilmiah Keperawatan

Orthopedi (JIKO)

Article history:

Received: January 28, 2022

Revised: February 10, 2022

Accepted: February 13, 2022

\title{
The Effect of Health Education During the Covid 19 Period on Increasing Knowledge in Comorbid Patients (Suspected) With Diabetes Mellitus (DM) At Harum Sisma Medika Hospital, Jakarta 2021
}

\author{
Rogayah $^{1}$, Husnul Fatimah Rahmah ${ }^{2}$, Hinggil Permana ${ }^{3}$, Al-Bahra ${ }^{4}$ \\ Sismadi College of Health Sciencesy, Jakarta-Indonesia ${ }^{1}$, Manajemen Pendidikan Islam- \\ Universitas Singaperbangsa Karawang-Indonesiaa ${ }^{2,3}$, Master in Informatics Engineering- Rahraja \\ University, Tangerang Indonesia ${ }^{4}$ \\ e-mail: rogayahtara77@gmail.com ${ }^{1}$, nullfatma@gmail.com ${ }^{2,3}$, albahra@ raharja.info $^{4}$
}

The purpose of this study was to determine the effect of health education during the Covid 19 period on increasing knowledge in comorbid (suspected) patients with Diabetes Mellitus (DM) at Harum Sisma Medika Hospital, Jakarta. This study uses a quantitative approach with a preexperimental research design, one group pre-post test design. The sample in this study was 18 respondents who were selected by purposive sampling technique. The study took place in the isolation ward of the Harum Sisma Medika Hospital, Jakarta. The instrument used is the DKQ-24 questionnaire (Diabetes Knowledge Questionnaire) with 24 question items. The test is a paired t test. The results showed that there was a difference in the mean score between knowledge before and after health education with the $\mathrm{p}$ value before and after being given health education related to covid 19, namely 0.002 ( $\mathrm{P}<0.05)$. Factors significantly associated with preventive behaviour are knowledge and education. Knowledge related to COVID-19 prevention behaviour is carried out by wearing masks, maintaining hand hygiene, and avoiding crowds. In a study of diabetic and nondiabetic patients, diabetic patients expressed concern about the risk of COVID19 infection. They changed behaviour and lifestyle due to the COVID-19 pandemic. Knowledge and attitudes are associated with COVID19 prevention behaviour.

Keywords: Health Education; Education Level; Comorbid Diabetes Mellitus

\section{Introduction}

One of the main causes of morbidity and mortality worldwide is diabetes. This condition is also closely associated with several microvascular and macrovascular complications. So that it will have an impact on overall patient survival [1]. The association between diabetes and infection has long been recognized clinically [2]. Infections caused by influenza and pneumonia, are common infections, but become more serious if experienced by older people with type 2 diabetes mellitus (T2DM) [3], [4]. However, it is still controversial whether diabetes increases susceptibility and impacts the outcome of infection, or the cardiovascular and renal comorbidities often associated with diabetes are the main factors involved [5].

In the current state of the SARS-CoV-2 pandemic, several studies have found no clear association between diabetes and severe disease [6], [7]. However, there are several reports from China [8], [9] and Italy [10] showing that older patients with chronic diseases, including diabetes, have a higher risk of contracting COVID-19 and this can lead to death.

Currently, there are sparse data on glucose metabolism and the development of acute complications of diabetes (eg, ketoacidosis) in patients infected with 
COVID-19. SARS-CoV-2 infection in diabetics may trigger higher stress conditions, with greater release of hyperglycemic hormones, eg, glucocorticoids and catecholamines, leading to elevated blood glucose levels and abnormal glucose variability [11]. Meanwhile, a retrospective study from Wuhan reported that approximately $10 \%$ of patients with T2DM and COVID-19 experienced at least one episode of hypoglycemia $\quad(<3.9 \mathrm{mmol} / \mathrm{L}) \quad$ [12]. Hypoglycemia has been shown to mobilize pro-inflammatory monocytes and increase platelet reactivity, contributing to higher cardiovascular mortality in patients with diabetes [13]. However, it remains unknown exactly how the inflammatory and immune responses occur in these patients, as well as whether hyper or hypoglycemia can alter the virulence of SARS-CoV-2, or the virus itself interferes with insulin secretion or glycemic control. In addition, the impact of treatment for ordinary diabetics who are also infected with COVID-19, as well as therapeutic approaches for COVID-19 on glucose regulation have not yet been determined.

Diabetes is a chronic inflammatory condition characterized by multiple metabolic and vascular abnormalities that can affect our response to pathogens [5]. Hyperglycemia and insulin resistance promote increased synthesis of glycosylation end products (AGEs) and proinflammatory cytokines, oxidative stress, in addition to stimulating the production of adhesion molecules that mediate tissue inflammation $[5,14]$. This inflammatory process may constitute the underlying mechanism leading to a higher predisposition to infection, with poorer outcomes than it is in patients with diabetes [5].

Several immune problems are associated with hyperglycemia, although the clinical relevance of some of these disorders is still not fully understood [15]. Poorly controlled diabetes is associated with inhibition of the proliferative response of lymphocytes to various types of stimuli [16], as well as impaired monocyte/macrophage and neutrophil function [5]. Abnormal delayedtype hypersensitivity reactions [15] and complement activation dysfunction [17]. The results of this study showed that exposure of pulmonary epithelial cells to high glucose concentrations significantly increased influenza virus infection and replication, suggesting that hyperglycemia may increase viral replication rapidly [18]. In animals, lung structural changes have been associated with diabetes, such as increased vascular permeability and alveolar epithelial collapse [19]. Meanwhile, diabetic patients generally show a significant reduction in forced vital capacity (FVC) and forced expiratory volume in one second (FEV1), which is associated with increased plasma glucose levels [20].

The purpose of this study was to determine the effect of health education during the Covid 19 period on increasing knowledge in comorbid (suspected) patients with Diabetes Mellitus (DM) at Harum Sisma Medika Hospital, Jakarta.

\section{Method}

This research is a quantitative research, with a pre-experimental research design, one group pre-post test design. The researcher deliberately gave treatment (health education) to respondents who were only grouped into one group, namely the intervention group with the aim of studying the effects of treatment and not controlling strictly.

There is an effect of Covid 19 DM health education on increasing knowledge of comorbid patients with DM. otogenic relaxation techniques and distraction in the intervention group II.

\section{Result and Discussion \\ Univariate Analysis}

Table 1. Distribution of characteristics of comorbid DM patients by age at the Sisma Medika Hospital,

\begin{tabular}{llccc}
\multicolumn{5}{c}{ Jakarta in 2021} \\
$\begin{array}{l}\text { Characte } \\
\text { ristics }\end{array}$ & Mean & SD & $\begin{array}{c}\text { Min- } \\
\text { Max }\end{array}$ & $95 \%$ CI \\
\hline Age & 45,7 & 11,0 & $33-65$ & $40,25-$ \\
& 2 & 02 & & 51,19 \\
\hline
\end{tabular}


Table 1 describes the average age of patients with comorbid DM, which is 45.72 with a standard deviation of 11.002 years. Where the youngest age is 33 years and the oldest 65 years. At $95 \%$ Confident Interval between $40.25-51.29$.

Table 2 Distribution of the characteristics of comorbid DM patients by gender, education, occupation, family history and recent education history at the hospital. Sisma Medika Jakarta in 2021

\begin{tabular}{|c|c|c|}
\hline Characteristics & Frequency & $\%$ \\
\hline \multicolumn{3}{|l|}{ Gender } \\
\hline Woman & 4 & 22,2 \\
\hline Man & 14 & 77,8 \\
\hline Total & 18 & 100 \\
\hline \multicolumn{3}{|l|}{ Education } \\
\hline Senior High School & 16 & 88,9 \\
\hline Diploma/Bachelor & 2 & 11,1 \\
\hline Total & 18 & 100 \\
\hline \multicolumn{3}{|l|}{ Work } \\
\hline Jobless & 9 & 50.0 \\
\hline Civil Servant & 1 & 5.6 \\
\hline Private & 4 & 22.2 \\
\hline Entrepreneur & 3 & 16.6 \\
\hline Retired & 1 & 5.6 \\
\hline Total & 18 & 100 \\
\hline \multicolumn{3}{|l|}{ Family History } \\
\hline Have & 9 & 50.0 \\
\hline Haven't & 9 & 50.0 \\
\hline Total & 18 & 100 \\
\hline \multicolumn{3}{|l|}{ Highest Education History } \\
\hline$<1$ month & 10 & 55.6 \\
\hline $1-6$ month & 2 & 11.1 \\
\hline 6 month & 6 & 33.3 \\
\hline Total & 18 & 100 \\
\hline \multicolumn{3}{|l|}{ Pre Education } \\
\hline Lack of Knowledge & 15 & 83.3 \\
\hline Enough Knowledge & 3 & 16.7 \\
\hline Total & 18 & 100 \\
\hline \multicolumn{3}{|l|}{ Post Education } \\
\hline Lack of Knowledge & 9 & 83.3 \\
\hline Enough Knowledge & 4 & 22.2 \\
\hline Good Knowledge & 5 & 27.8 \\
\hline Total & 18 & 100 \\
\hline
\end{tabular}

Table 2 illustrates that the distribution of the characteristics of respondents (gender, education, occupation, family history, recent education history, pre education, post education) at Harum Sisma Medika Hospital Jakarta in 2021 who experienced comorbid DM with a total of 18 . Most of them were male $(77.8 \%)$ and female $(22.47 \%)$. The distribution of work of comorbid DM patients is dominated by not working or housewives $50.0 \%$, education is dominated by high school $88.9 \%$.

Judging from the family history there is $50.0 \%$ and no $50.0 \%$, the most recent educational history is dominated by patients who received less than 1 month of education, pre-education or before being given health education in comorbid DM patients dominated by $15 \%$ less knowledge and post-education after being given education Health knowledge in comorbid DM patients is $50.0 \%$ less knowledge and $27.8 \%$ good knowledge.

\section{Bivariate Analysis}

Table 3 Effect of Covid 19 Health Education on Increasing Knowledge of Comorbid Patients with Diabetes Mellitus (DM) at Harum Sisma Medika Hospital 2021

\begin{tabular}{|c|c|c|c|c|c|c|}
\hline $\begin{array}{l}\text { Education } \\
\text { Health } \\
\text { Covid } 19\end{array}$ & & $\mathrm{~N}$ & Mean & $\begin{array}{c}\text { Std. } \\
\text { Deviasi }\end{array}$ & $\begin{array}{l}\mathrm{P} \\
\text { Value }\end{array}$ & $\begin{array}{c}\mathrm{p} \\
\text { Val } \\
\text { ue }\end{array}$ \\
\hline \multirow{2}{*}{$\begin{array}{c}\text { Knowled } \\
\text { ge }\end{array}$} & Pre & 18 & 9,22 & 3,154 & 0.02 & 0,0 \\
\hline & Post & 18 & 13,06 & 5,693 & & 02 \\
\hline
\end{tabular}

Based on the table above, it can be seen that the knowledge of comorbid DM patients with the average value before being given health education related to covid 19 was 9.22 and the standard deviation was 3.154. DM comorbid patients after being given health education related to covid 19 with an average value of 13.06 and a standard deviation of 5.693. It can be seen that the average value before and after being given health education related to covid 19 was -3.833 with a standard deviation of 4.328. The $\mathrm{p}$ value before and after being given health education related to covid 19 is 0.002 .

\section{Discussion}

The knowledge of comorbid DM patients with the average value before being given health education related to Covid 19 was 9.22 and the standard deviation was 3.154. DM comorbid patients after being given health education related to covid 19 with an average value of 13.06 and a standard deviation of 5.693. It can be seen that the average value before and after being given health education related to covid 19 was - 
3.833 with a standard deviation of 4.328 . The $\mathrm{p}$ value before and after being given health education related to covid 19 was $0.002(\mathrm{P}<0.05)$.

Factors significantly associated with preventive behaviour are knowledge (Pvalue 0.0001), attitude (P-value 0.0001), and education (P-value 0.0001). Research in Northwest Ethiopia, Vietnam, South Korea, and China also showed that knowledge is significantly related to COVID-19 prevention practices $[21 ; 22 ; 23 ; 24]$. Good knowledge is associated with good COVID19 prevention behaviour [25]. Based on research in South Korea, knowledge related to COVID-19 prevention behaviour is carried out by wearing masks, maintaining hand hygiene, and avoiding crowds [23].

In a study of diabetic and nondiabetic patients, diabetic patients expressed concern about the risk of COVID19 infection. They changed behaviour and lifestyle due to the COVID-19 pandemic [26]. Knowledge and attitudes are associated with COVID-19 prevention behaviour [27; 24; 28]. Good knowledge and a positive attitude are significantly associated with COVID-19 prevention behaviour compared to other factors [29]. Meanwhile, according to a 2020 study in Sudan, knowledge and attitudes do not significantly affect COVID19 prevention behaviour [30]. Knowledge and attitudes are part of the predisposing factors influencing behaviour change [31]. Efforts to increase knowledge and encourage positive attitudes are needed for diabetic patients to make behavioural changes to prevent COVID-19.

Health education aims to change the behavior of individuals, groups, and communities towards positive things that are planned through the learning process. Behavior change in health education covers 3 domains, namely knowledge, attitudes, and skills through the health education process.

Health education conducted by health workers can increase a person's knowledge. Knowledge is the result of knowing that occurs after people sense a certain object.
Sensing occurs through the five human senses, namely sight, hearing, smell, taste and touch. Most of the knowledge is acquired through the eyes and ears [32].

\section{Conclusion}

Factors significantly associated with preventive behaviour are knowledge and education. Knowledge related to COVID-19 prevention behaviour is carried out by wearing masks, maintaining hand hygiene, and avoiding crowds. In a study of diabetic and nondiabetic patients, diabetic patients expressed concern about the risk of COVID19 infection. They changed behaviour and lifestyle due to the COVID19 pandemic. Knowledge and attitudes are associated with COVID-19 prevention behaviour.

\section{References}

[1]. Williams R., Karuranga S., Malanda B., Saeedi P., Basit A., Besançon S. Global and regional estimates and projections of diabetes-related health expenditure: results from the International Diabetes Federation Diabetes Atlas. Diabetes Res Clin Pract. 2020;162 doi: 10.1016/j.diabres .2020.108072. [PubMed]

[CrossRef] [Google Scholar]

[2]. Pearson-Stuttard Jonathan, Blundell Samkeliso, Harris Tess, Cook Derek G, Critchley Julia. Diabetes and infection: assessing the association with glycaemic control in populationbased studies. Lancet Diabetes Endocrinol. 2016;4(2):148-158. doi: 10.1016/S2213-8587(15)00379-

4. [PubMed] [CrossRef] [Google
Scholar]

[3]. McDonald H.I., Nitsch D., Millett E.R.C., Sinclair A., Thomas S.L. New estimates of the burden of acute community-acquired infections among older people with diabetes mellitus: a retrospective cohort study using linked electronic health records. Diabet Med. 2014;31(5):606-614. doi: 10.1111/dme.2014.31.issue- 
510.1111/dme.12384. [PMC free $\underline{\text { article] [PubMed] [CrossRef] [Google }}$ Scholar]

[4]. Li Sen, Wang Jiaxin, Zhang Biao, Li Xinyi, Liu Yuan. Diabetes mellitus and cause-specific mortality: a population-based study. Diabetes Metab J. 2019;43(3):319. doi: 10.4093/dmj.2018.0060. [PMC free article] [PubMed] [CrossRef] [Google Scholar]

[5]. Knapp Sylvia. Diabetes and infection: is there a link? - A minireview. Gerontology. 2013;59(2):99104.

doi: 10.1159/000345107. [PubMed] [CrossRef] [Google Scholar]

[6]. Zhang J.J., Dong X., Cao Y.Y., Yuan Y.D., Yang Y.B., Yan Y.Q. Clinical characteristics of 140 patients infected with SARS-CoV-2 in Wuhan, China. Allergy. 2020 doi: 10.1111/all.14238. Epub 2020/02/23 PubMed PMID: 32077115. [PubMed]

[CrossRef] [Google Scholar]

[7]. Lippi G., Plebani M. Laboratory abnormalities in patients with COVID2019 infection. Clin Chem Lab Med. 2020 doi: 10.1515/cclm-20200198. Epub 2020/03/03 PubMed PMID: $32119647 . \quad$ [PubMed] [CrossRef] [Google Scholar]

[8]. Guan W.J., Ni Z.Y., Hu Y., Liang W.H., Ou C.Q., He J.X. Clinical characteristics of coronavirus disease 2019 in China. N Engl J Med. 2020:113. Epub 2020/02/29. PubMed PMID: 32109013. [Google Scholar]

[9]. Wu Zunyou, McGoogan Jennifer M. Characteristics of and important lessons from the coronavirus disease 2019 (COVID-19) outbreak in China: summary of a report of 72314 cases from the Chinese Center for Disease Control and Prevention. JAMA. 2020;323(13):123.

[10]. Onder G., Rezza G., Brusaferro S. Case-fatality rate and characteristics of patients dying in relation to COVID-
19 in Italy. JAMA. 2020

doi: 10.1001/jama.2020.4683. Epub

2020/03/24 PubMed PMID:

32203977.

[PubMed]

[CrossRef] [Google

Scholar]doi: 10.1001/jama.2020.2648.

[PubMed] [CrossRef] [Google

$\underline{\text { Scholar] }}$

[11]. Wang Aihong, Zhao Weibo, Xu Zhangrong, Gu Jianwen. Timely blood glucose management for the outbreak of 2019 novel coronavirus disease (COVID-19) is urgently needed. Diabetes Res Clin Pract. 2020;162:108118.

doi: 10.1016/j.diabres.2020.108118. [ PMC free article] [PubMed] [CrossRef] [Google Scholar]

[12]. Zhou J., Tan J. Diabetes patients with COVID-19 need better care. Metabolism. 2020 doi: 10.1016/j.metabol.2020.154216. Epub 2020/03/30. PubMed PMID: 32220612; PubMed Central PMCID: PMCPMC7102634. [PMC free article] [PubMed] [CrossRef] [Google Scholar]

[13]. Iqbal A., Prince L.R., Novodvorsky P., Bernjak A., Thomas M.R., Birch L. Effect of hypoglycemia on inflammatory responses and the response to low-dose endotoxemia in humans. $J$ Clin Endocrinol Metab. 2019;104(4):1187-1199.

doi: 10.1210/jc.2018-01168. Epub

2018/09/27. PubMed PMID: 30252067; PubMed Central PMCID: PMCPMC6391720. [PMC free article] [PubMed] [CrossRef] [Google Scholar]

[14]. Petrie John R., Guzik Tomasz J., Touyz Rhian M. Diabetes, hypertension, and cardiovascular disease: clinical insights and vascular mechanisms. Canadian

Cardiol. 2018;34(5):575-584.

doi: 10.1016/j.cjca.2017.12.005. [PM $\mathrm{C}$ free article] [PubMed] [CrossRef] [Google Scholar] 
[15]. Geerlings S.E., Hoepelman A.I. Immune dysfunction in patients with diabetes mellitus (DM) FEMS Immunol Med Microbiol. 1999;26(34):259-265. doi: $10.1111 /$ j.1574695X.1999.tb01397.x. Epub

\begin{tabular}{|c|c|}
\hline $\begin{array}{l}9 / 11 / 27 \\
75137\end{array}$ & PubMed \\
\hline
\end{tabular}

[CrossRef] [Google Scholar]

[16]. Moutschen M.P., Scheen A.J., Lefebvre P.J. Impaired immune responses in diabetes mellitus: analysis of the factors and mechanisms involved. Relevance to the increased susceptibility of diabetic patients to specific infections. Diabete Metab. 1992;18(3):187-201. Epub 1992/05/01. PubMed PMID: 1397473. [PubMed] [Google Scholar]

[17]. Ilyas R., Wallis R., Soilleux E.J., Townsend P., Zehnder D., Tan B.K. High glucose disrupts oligosaccharide recognition function via competitive inhibition: a potential mechanism for immune dysregulation in diabetes mellitus. Immunobiology. 2011;216(12):126-131.

doi: 10.1016/j.imbio.2010.06.002. Epu b 2010/08/03. PubMed PMID: 20674073; PubMed Central PMCID: PMCPMC3088832. [PMC free $\underline{\text { article] [PubMed] [CrossRef] [Google }}$ $\underline{\text { Scholar] }}$

[18]. Kohio Hinissan P., Adamson Amy L. Glycolytic control of vacuolar-type ATPase activity: a mechanism to regulate influenza viral infection. Virology. 2013;444(1-

2):301-309.

doi: 10.1016/j.virol.2013.06.026. [Pub Med] [CrossRef] [Google Scholar]

[19]. Popov D., Simionescu M. Alterations of lung structure in experimental diabetes, and diabetes associated with hyperlipidaemia in hamsters. Eur Respir J. 1997;10(8):1850-1858. doi: 10.1183/09031936.97.10081850. Epub 1997/08/01 PubMed PMID: 9272930.

[PubMed]

\section{[CrossRef] [Google Scholar]}

[20]. Lange P., Groth S., Kastrup J., Mortensen J., Appleyard M., Nyboe J. Diabetes mellitus, plasma glucose and lung function in a cross-sectional population study. Eur Respir J. 1989;2(1):14-19. Epub 1989/01/01 PubMed PMID: 2651148. [PubMed] [Google Scholar]

[21]. Akalu, Y., Ayelign, B. and Molla, M. D. (2020) 'Knowledge, Attitude and Practice Towards COVID-19 Among Chronic Disease Patients at Addis Zemen Hospital, Northwest Ethiopia', Infection and Drug Resistance, Volume 13, pp. 1949-1960. doi: https://doi.org/10.2147/IDR.S258736.

[22]. Huynh, G. et al. (2020) 'Knowledge, Attitude, and Practices Regarding COVID-19 Among Chronic Illness Patients at Outpatient Departments in Ho Chi Minh City, Vietnam', Risk Management and Healthcare Policy, Volume 13, pp. 1571-1578. doi: https://doi.org/10.2147/RMHP.S26887 6.

[23]. Lee, M., Kang, B. and You, M. (2021) 'Knowledge, attitudes, and practices (KAP) toward COVID-19: a crosssectional study in South Korea', BMC Public Health, 21(1), p. 295. doi: https://doi.org/10.1186/s12889021- 10285-y.

[24]. Zhong, B.-L. et al. (2020) 'Knowledge, attitudes, and practices towards COVID- 19 among Chinese residents during the rapid rise period of the COVID-19 outbreak: a quick online cross-sectional survey', International Journal of Biological Sciences, 16(10), pp. 1745- 1752. doi: https://doi.org/10.7150/ijbs.45221.

[25]. Melesie Taye, G. et al. (2020) 'COVID-19 Knowledge, Attitudes, and Prevention Practices Among People with Hypertension and Diabetes Mellitus Attending Public Health Facilities in Ambo, Ethiopia', Infection and Drug Resistance, Volume 13, pp. 4203-4214. doi: https://doi.org/10.2147/IDR.S283999 
[26]. Yan, A. F. et al. (2020) 'Perceived risk, behavior changes and Healthrelated outcomes during COVID-19 pandemic: Findings among adults with and without diabetes in China', Diabetes Research and Clinical Practice, 167(January), p. 108350. doi: https://doi.org/10.1016/j.diabres.202 $\underline{0.108350 .}$.

[27]. Pal, R. et al. (2020) 'Knowledge, attitudes and practices towards COVID-19 among young adults with Type 1 Diabetes Mellitus amid the nationwide lockdown in India: A cross-sectional survey', Diabetes Research and Clinical Practice, 166(January), p. 108344. doi: https://doi.org/10.1016/j.diabres.202 0.108344.

[28]. Reuben, R. C. et al. (2021) 'Knowledge, Attitudes and Practices Towards COVID19: An Epidemiological Survey in NorthCentral Nigeria', Journal of Community Health, 46(3), pp. 457470.

doi: https://doi.org/10.1007/s10900-02000881-1.

[29]. Andarge, E. et al. (2020) 'Intention and Practice on Personal Preventive Measures Against the COVID-19 Pandemic Among Adults with Chronic Conditions in Southern Ethiopia: A Survey Using the Theory of Planned Behavior', Journal of Multidisciplinary Healthcare, Volume 13, pp. 1863-1877. doi: https://doi.org/10.2147/JMDH.S28470 7.

[30]. Mohamed, A. A. O. et al. (2021) 'Knowledge, attitude and practice of the Sudanese people towards COVID19: an online survey', BMC Public Health, 21(1), p. 274. doi: https://doi.org/10.1186/s12889-02110319-5.

[31]. Porter, C. M. (2016) 'Revisiting PrecedeProceed: A leading model for ecological and ethical health promotion', Health Education Journal,
75(6), pp. 753-764. doi: 10.1177/0017896915619645

[32]. Fitriani, Sinta. 2017. Promosi Kesehatan. Yogyakarta : Graha Ilmu. 